OPEN ACCESS

Edited by:

Peng Yao,

Ocean University of China, China

Reviewed by:

Chris Groves,

Western Kentucky University,

United States

Xiaojuan Feng,

Institute of Botany, Chinese Academy

of Sciences, China

*Correspondence:

Zaihua Liu

liuzaihua@vip.gyig.ac.cn

Specialty section:

This article was submitted to

Biogeoscience,

a section of the journal

Frontiers in Earth Science

Received: 26 October 2020 Accepted: 18 August 2021

Published: 31 August 2021

Citation:

Liu Z, Yan H and Zeng S (2021) Increasing Autochthonous Production in Inland Waters as a Contributor to the Missing Carbon Sink.

Front. Earth Sci. 9:620513. doi: 10.3389/feart.2021.620513

\section{Increasing Autochthonous Production in Inland Waters as a Contributor to the Missing Carbon Sink}

\author{
Zaihua Liu ${ }^{1,2 *}$, Hao Yan ${ }^{1}$ and Sibo Zeng ${ }^{1,3}$ \\ ${ }^{1}$ State Key Laboratory of Environmental Geochemistry, Institute of Geochemistry, Chinese Academy of Sciences (CAS), Guiyang, \\ China, ${ }^{2}$ CAS Center for Excellence in Quaternary Science and Global Change, Xi'an, China, ${ }^{3} G e o p h y s i c s$ Section, Institute of \\ Geological Sciences, Freie Universität Berlin, Berlin, Germany
}

Accounting for the residual land sink (or missing carbon sink) has become a major budget focus for global carbon cycle modelers. If we are not able to account for the past and current sources and sinks, we cannot make accurate predictions about future storage of fossil fuel combustion emissions of carbon in the terrestrial biosphere. Here, we show that the autochthonous production (AP) in inland waters appears to have been strengthening in response to changes in climate and land use, as evidenced by decreasing $\mathrm{CO}_{2}$ emissions from and increasing dissolved organic carbon storage and/or organic carbon burial in inland waters during recent decades. The increasing AP may be due chiefly to increasing aquatic photosynthesis caused by global warming and intensifying human activities. We estimate that the missing carbon sink associated with the strengthening AP in inland

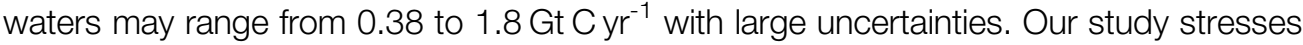
the potential role that AP may play in the further evolution of the global carbon cycle. Quantitative estimates of future freshwater AP effects on the carbon cycle may also help to guide the action needed to reduce carbon emissions, and increase carbon sinks in terrestrial aquatic ecosystems.

Keywords: inland waters, aquatic photosynthesis, global carbon cycle, climate change, land-use change, autochthonous production, missing carbon sink

\section{INTRODUCTION}

For the past three centuries $\mathrm{CO}_{2}$ emissions from human activities, including the burning of fossil fuels and extensive land-use changes, have unbalanced the natural cyclical growth and rise of $\mathrm{CO}_{2}$ in the atmosphere and the accumulation of $\mathrm{CO}_{2}$ in the oceans (Broecker et al., 1979; Houghton et al., 1990; Tans et al., 1990; Houghton, 2003; Melnikov and O’Neill, 2006; Houghton, 2007; Ballantyne et al., 2012; Ciais et al., 2013; Houghton et al., 2018; Kirschbaum et al., 2019). This imbalance is recognized as the residual land sink (or missing carbon sink) in the global carbon cycle. The sink is estimated to amount to $2.5 \pm 1.3 \mathrm{Gt} \mathrm{C} \mathrm{yr}^{-1}$ for the decade, 2002-2011 (Ciais et al., 2013). Various hypotheses have been proposed to explain it, the foremost among them being the finding that increased atmospheric $\mathrm{CO}_{2}$ concentrations have boosted photosynthesis and the burial of carbon in terrestrial ecosystems (King et al., 1995; Kheshgi et al., 1996). Estimates of the biosphere's $\mathrm{CO}_{2}{ }^{-}$ enhanced drawdown, however, are much smaller than the missing carbon sink. There is evidence that nitrogen might be the cause (Schindler and Bayley, 1993). Over the last century human activity released more than twice as much nitrogen as in previous centuries. Nitrogen is the nutrient that most accelerates growth in forests (Vitousek et al., 1997). However, Nadelhoffer et al. (1999) 


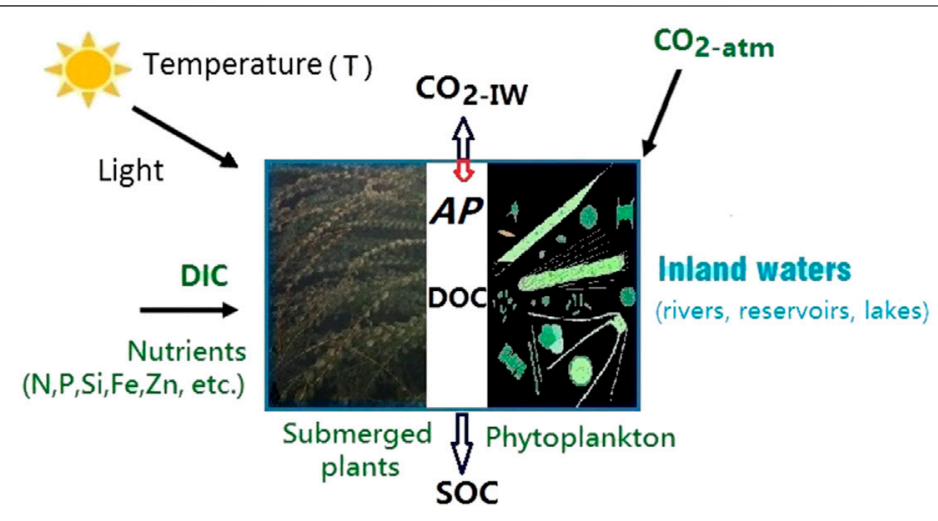

Changes in climate and land-use

$\begin{array}{ll}\text { Increasing } & \text { Strengthening } \\ \mathrm{T}, \mathrm{DIC}\left(\mathrm{CO}_{2}-\mathrm{atm}\right), \mathrm{N}, \mathrm{P}, \text { etc. } & \begin{array}{l}\text { Increasing } \\ \text { DOC \& } \mathrm{SOC} \\ \text { but decreasing } \mathrm{CO}_{2}-\mathrm{IW}\end{array}\end{array}$

FIGURE 1 | A conceptual model for increasing the strength of the autochthonous production (AP) through climate change (increasing atmospheric $\mathrm{CO}_{2}$, temperature, etc.) and land-use change (increasing nutrient inputs, including dissolved inorganic carbon-DIC, nitrogen- $\mathrm{N}$, phosphorus- $\mathrm{P}$, etc.). The strengthening $\mathrm{AP}$ is indicated by decreasing dissolved $\mathrm{CO}_{2}$ and increasing dissolved organic carbon (DOC) and sedimentary organic carbon (SOC) in inland waters, which contribute to the missing carbon sink.

calculated that such larger nitrogen contributions increased the carbon flux by only $0.25 \mathrm{Gt} \mathrm{C} \mathrm{yr}^{-1}$ at most. Therefore, where the remainder of the missing carbon sink is hiding in the land has become a mystery (Broecker and Peng, 1998; Schindler, 1999). Liu et al. (2010) and Liu et al. (2018) have found the importance of the aquatic autochthonous production (AP) in $\mathrm{CO}_{2}$ drawdown (or the missing carbon sink).

Here, we show that the AP (Figure 1) appears to have been strengthening in response to the changes of climate and land use, as evidenced by decreasing $\mathrm{CO}_{2}$ emissions from and increasing dissolved organic carbon (DOC) storage and/or organic carbon (OC) burial in these waters during recent decades (Bianchi et al., 2004; Wang et al., 2007; Downing et al., 2008; Finlay et al., 2009; Sun et al., 2010; Heathcote and Downing, 2012; Anderson et al., 2013; Brothers et al., 2013; Anderson et al., 2014; Pacheco et al., 2014; Finlay et al., 2015; Ran et al., 2015; Wang et al., 2018; Anderson et al., 2020; He et al., 2020; Ran et al., 2021). There are also some studies that show there is no trend in $\mathrm{CO}_{2}(\mathrm{Nydahl}$ et al., 2017) and that increased lake OC burial is due to greater levels of terrestrial production (Heathcote et al., 2015). The reason for this may be that the former examples present the cases dominated by the organic carbon increase from aquatic production (with consumption of dissolved $\mathrm{CO}_{2}$ ), which results in increasing $\mathrm{OC}$ but decreasing $\mathrm{pCO}_{2}$ in inland waters, while the latter examples present the cases dominated by the $\mathrm{OC}$ increase from terrestrial sources, which results in increasing OC but increasing or no $\mathrm{pCO}_{2}$ trends in inland waters. However, according to our thorough review the former positiveexamples seems more universal (Anderson et al., 2020; Ran et al., 2021). We estimate that the missing carbon sink associated with the strengthening of the AP in inland water may range from 0.38 to $1.8 \mathrm{Gt} \mathrm{Cyr}^{-1}$. The considerable uncertainties here may be reduced in the future by integrating all terrestrial carbon cycling processes to better resolve the inland waters carbon budgets (Cardille et al., 2007; Hanson et al., 2015). This study stresses the potential role that AP may play in the evolution of the global carbon cycle.

\section{OVERVIEW OF THE INCREASING STRENGTH OF THE AP}

The role of inland waters (particularly rivers, lakes and reservoirs) have only recently been integrated into the terrestrial carbon cycle. Cole et al. (2007) built a schematic budget for evaluating the contribution of terrestrial aquatic ecosystems to the global carbon cycle, using published data on gas exchange, sediment accumulation and carbon transportation for various different aquatic systems. They showed that inland waters receive $1.9 \mathrm{GtC} \mathrm{yr}^{-1}$ from terrestrial catchments, of which $0.2 \mathrm{Gt} \mathrm{C} \mathrm{yr}^{-1}$ is buried in their aquatic sediments, 0.8 $\mathrm{Gt} \mathrm{C} \mathrm{yr}^{-1}$ is returned to the atmosphere in gas exchange and the remaining $0.9 \mathrm{Gt} \mathrm{C} \mathrm{yr}^{-1}$ is discharged into the sea. Therefore, almost twice as much carbon enters inland aquatic systems from the land as is delivered from them to the ocean. It is thus concluded that although the global area of inland waters is small, these freshwater aquatic systems can affect regional carbon balances. Tranvik et al. (2009) demonstrated that the global annual $\mathrm{CO}_{2}$ emissions from inland waters to the atmosphere are of approximately the same magnitude as the $\mathrm{CO}_{2}$ consumption by the oceans. They further show that the global storage of OC in terrestrial aquatic sediments surpasses organic carbon sequestration on the sea floor. This is because the rate of accumulation of sediments and their preservation are both higher in inland waters by a factor of about 50 (Einsele et al., 2001).

However, the carbon fluxes in inland waters are often assumed to remain unchanged regardless of the $\mathrm{CO}_{2}$ level in the 


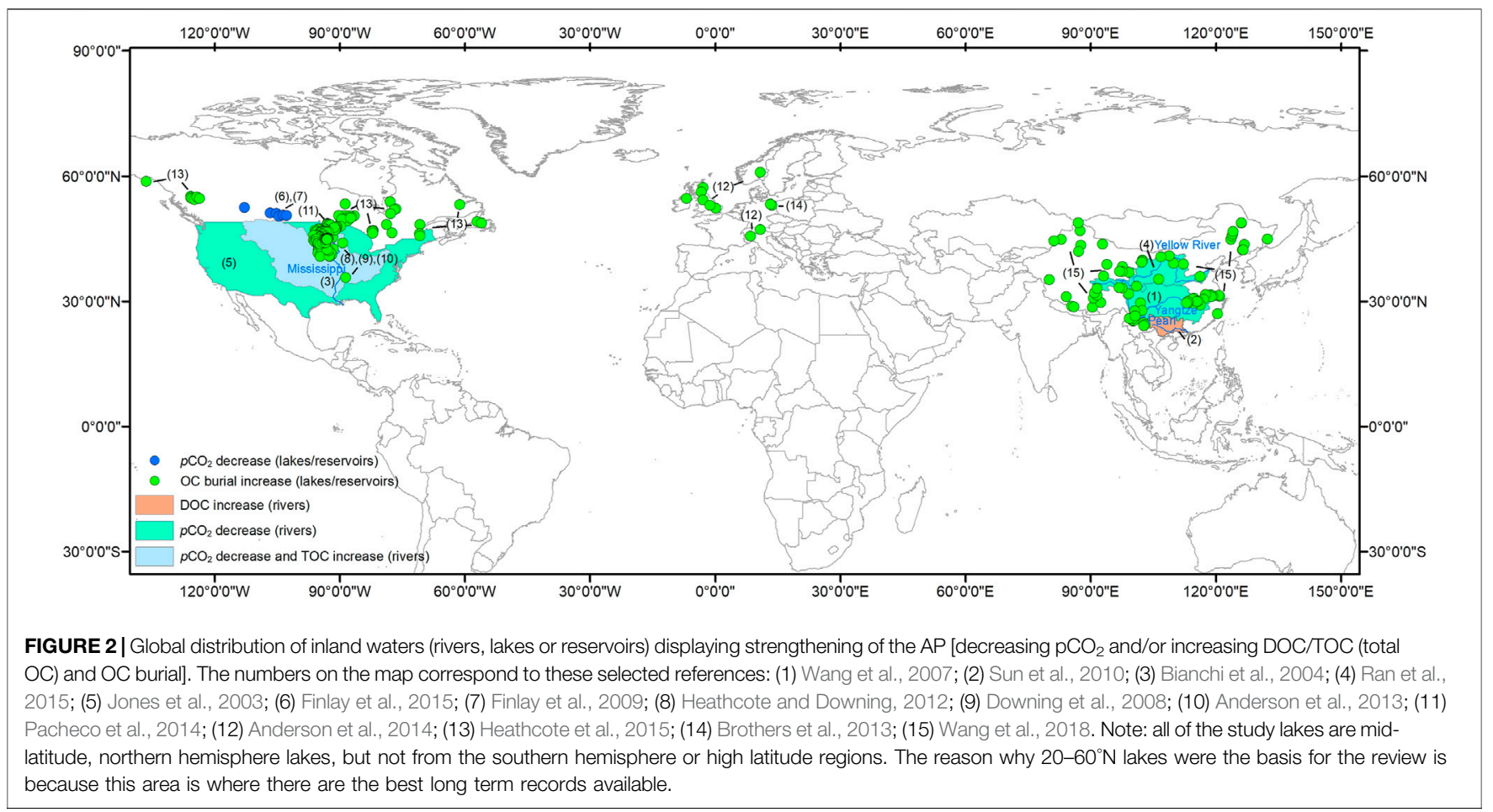

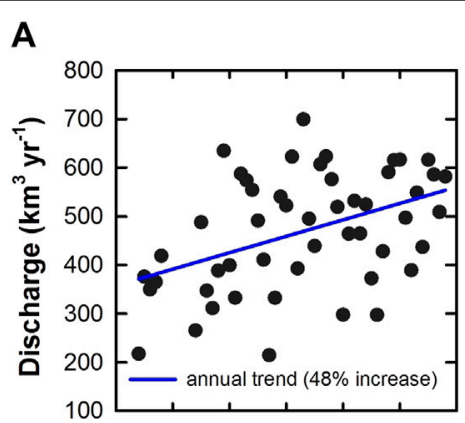

D

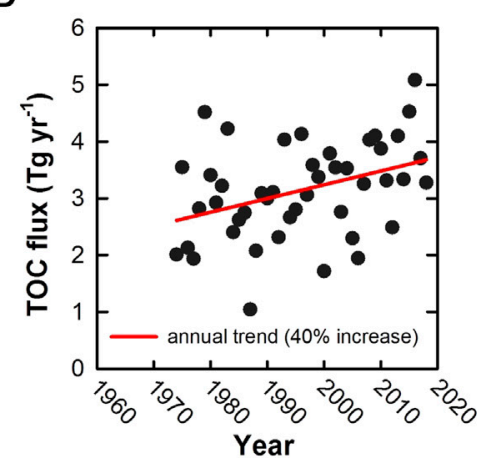

B

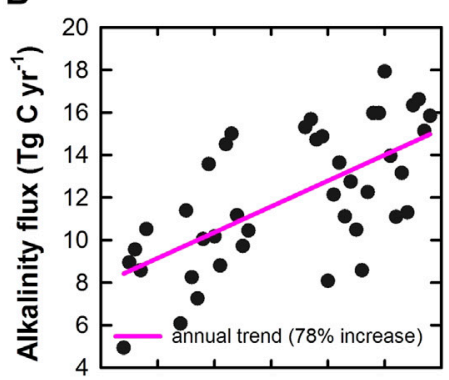

E

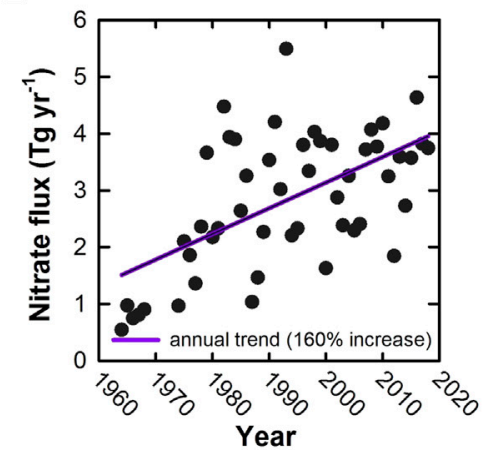

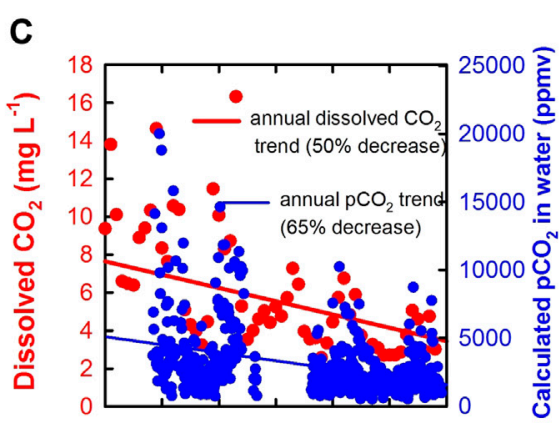

$\mathbf{F}$

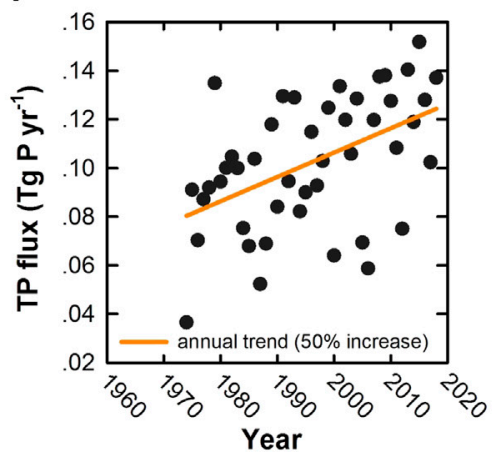

FIGURE 3 | Discharge and mass transport in the Mississippi River. Panels show time series of annual discharge of water (A); alkalinity flux (B); dissolved CO 2 and $\mathrm{pCO}_{2}$ (C); TOC flux (D); Nitrate flux (E); and TP (total phosphorus) flux (F). All data are abstracted directly or calculated from the USGS Water Data for the Nation (https:// waterdata.usgs.gov/nwis) at the St. Francisville USGS site 07373420. All depicted linear regression relationships are significant at the $p<0.01$ level. 


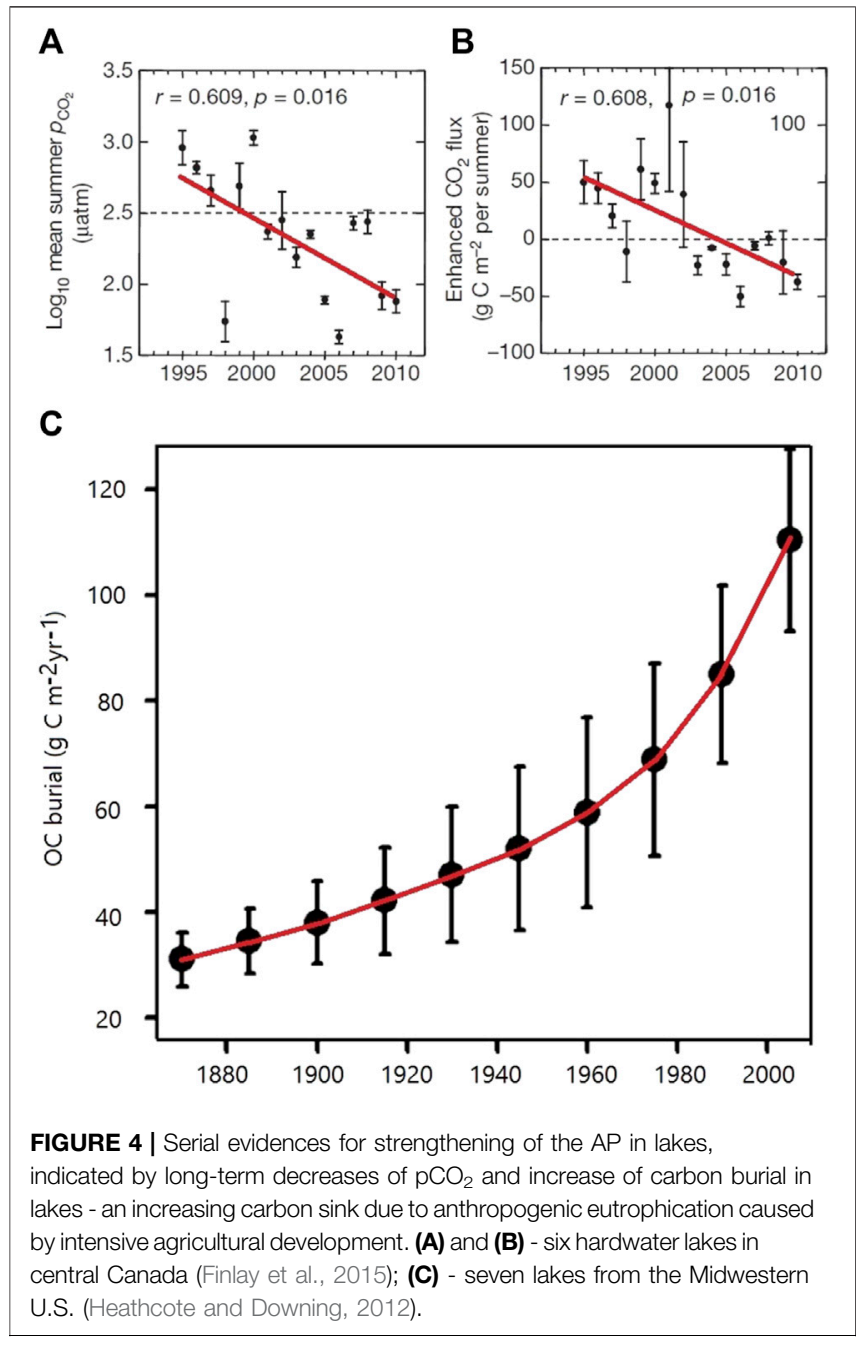

atmosphere (Sabine et al., 2004; Ciais et al., 2013). In addition, there is no quantitative differentiation of organic carbon flux sources between the allochthonous (terrigenous) and the autochthonous (formed in inland waters by the AP effectWaterson and Canuel, 2008; Liu et al., 2010; Yang et al., 2016; Liu et al., 2018) in these global studies. This impedes further understanding of the behaviour of the carbon cycle in inland waters and thus increases the uncertainty in global carbon budgeting.

Following a thorough review of previous publications, we have found that the AP in inland waters (Liu et al., 2010; Liu et al., 2018) appears to have been strengthening in response to the changes of climate and land-use (Figures 1, 2), as evidenced by decreasing $\mathrm{CO}_{2}$ emissions from and increasing DOC storage and OC burial in inland waters during the past 60-150 years (e.g., Figures 3-5).

Carbon cycling in inland waters has been studied both in terms of the magnitude and global significance of carbon that is released to the atmosphere (Richey et al., 2002; Raymond et al., 2013) and that which is stored in the sediments (Mulholland and Elwood, 1982; Dean and Gorham, 1998; Stallard, 1998; Einsele et al., 2001). Interestingly, there have been few studies examining whether measures of carbon release flux are directly related to how much carbon is being stored in sediments at the same time (Hanson et al., 2004). However, Flanagan et al. (2006) found that $\mathrm{CO}_{2}$ saturation in water is inversely correlated with the rate of sedimentation, suggesting that calculation of $\mathrm{CO}_{2}$ fluxes from inland waters should take this into consideration.

The AP has been recognized by oceanographers as the interaction between biota and sedimentation in the oceanic carbon cycle. Flanagan et al. (2006) thus thoroughly examined sedimentation types and rates and food web structure as factors controlling the saturation of $\mathrm{CO}_{2}$, and proposed a common framework for inland waters and marine ecosystems. Later, Knoll et al. (2013) described the regional significance of Ohio reservoirs for $\mathrm{OC}$ sequestration and $\mathrm{CO}_{2}$ emissions, finding that the reservoirs bury up to four times more OC, and release less than $25 \%$ of the $\mathrm{CO}_{2}$, than predicted based on their area and recent global mean estimates in lentic ecosystems, which indicates that temperate hard-water reservoirs are important OC sinks rather than $\mathrm{CO}_{2}$ sources.

\section{Decrease in the $\mathrm{CO}_{2}$ Degassing Flux in Inland Waters in Recent Decades}

A decrease in $\mathrm{CO}_{2}$ degassing flux seems to be a global phenomenon both in rivers (Wang et al., 2007; Ran et al., 2015; Ran et al., 2021) and lakes (Finlay et al., 2009; Finlay et al., 2015) (Figure 2), that is likely to be influenced by anthropogenic activity and climate change.

Jones et al. (2003) calculated the partial pressure of $\mathrm{CO}_{2}$ $\left(\mathrm{pCO}_{2}\right)$ in 417 streams and rivers distributed across the contiguous United States over a 22 year period. They found that $\mathrm{pCO}_{2}$ declined by $78.4 \mathrm{ppmv} \mathrm{a}^{-1}$ (or 58\%) between 1973 and 1994. Although the leading cause for the decline was attributed to large-scale declines in terrestrial $\mathrm{CO}_{2}$ production and import into aquatic ecosystems during this 22-year period, increased in-river primary production was likely a significant factor because it coincides with significantly increased oxygen saturation in the aquatic environment (Jones et al., 2003). For the Mississippi River (the largest in North America, draining an area of $\sim 3$ million $\mathrm{km}^{2}$ ), we have found a similar decrease in $\mathrm{pCO}_{2}$, about $65 \%$ in the last 50 years (Figure 3C). In addition, Finlay et al. (2015) found that hardwater lakes in the northern United States plains have shifted progressively from being substantial $\mathrm{CO}_{2}$ sources in the mid-1990s to sequestering $\mathrm{CO}_{2}$ by 2010 (Figures 4A,B), with a steady increase in annual mean $\mathrm{pH}$. This decrease in $\mathrm{CO}_{2}$ efflux and increase in $\mathrm{pH}$ were attributed to the atmospheric warming and nutrient-induced increase in aquatic photosynthesis.

In Asia, Wang et al. (2007) found that the dissolved $\mathrm{CO}_{2}$ in the Yangtze River (the largest river in Eurasia, draining 1.8 million $\mathrm{km}^{2}$ ) decreased greatly over the period, 1960-2000 (Figure 5B), together with a marked increase in nutrient concentrations (e.g., $>500 \%$ increase in $\mathrm{NO}_{3}{ }^{-}$; Figure 5C). They showed that although the discharge and DIC flux had remained essentially constant in the Yangtze, dissolved $\mathrm{CO}_{2}$ was oversaturated wrt atmospheric $\mathrm{CO}_{2}$ and its concentration had displayed a decreasing trend since the 1960s. This decrease in 

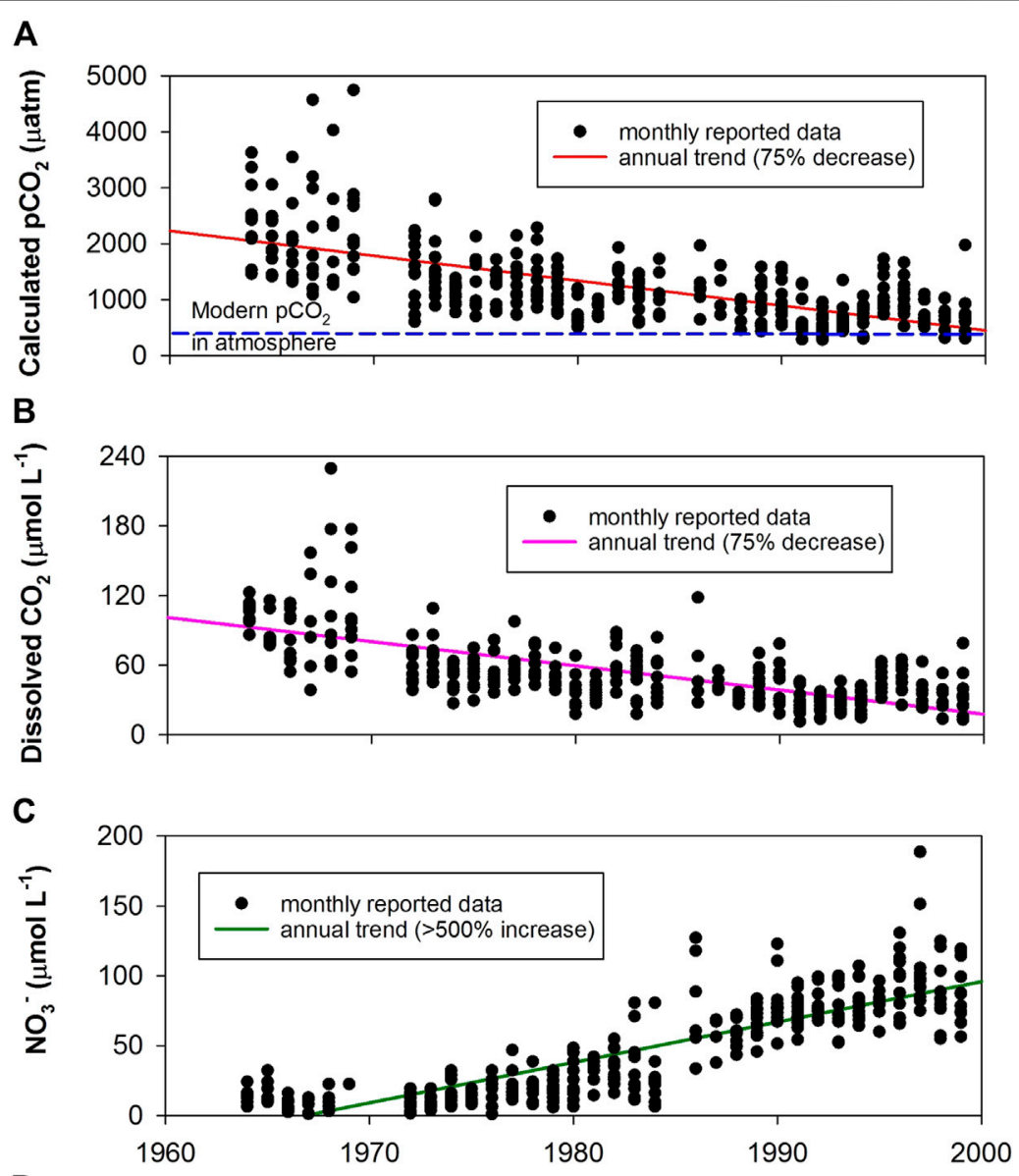

D

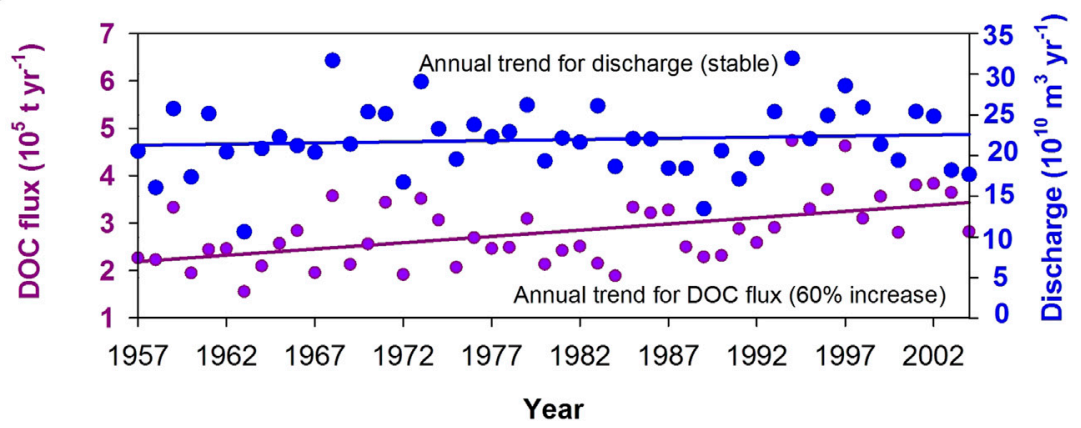

FIGURE 5 | Serial evidences for the increasing strength of the AP in rivers, indicated by long-term decreasing dissolved $\mathrm{CO}_{2}$ and increasing DOC flux in two of China's bigger rivers as an increasing missing carbon sink is created by human activities that include reservoir/dam construction and domestic/agricultural effluents (increasing nutrient inputs, e.g., $\mathrm{NO}_{3}{ }^{-}$). (A-C) - Yangtze River (Wang et al., 2007); (D) - Xijiang River (Sun et al., 2010).

dissolved $\mathrm{CO}_{2}$ concentrations was ascribed to variations in the riverine trophic level and stream damming activities in the Yangtze drainage basin. Due to substantial economic innovations (e.g., agriculture and industry development) across the Yangtze watershed, fertilizer applications and physical regulation have significantly altered the original state of the river. Its ecosystem and hydrological condition have been evolving toward the "lacustrine/reservoir" autotrophic type prevailing with plankton. Consequently, average $\mathrm{CO}_{2}$ degassing flux from the river had declined by $\sim 75 \%$ from the 1960s (58.8 $\mathrm{Mt} \mathrm{C} \mathrm{yr}^{-1}$ ) to the 1990s (15.3 $\mathrm{Mt} \mathrm{C} \mathrm{yr}^{-1}$; Wang et al., 2007).

Similar decreasing trends in $\mathrm{pCO}_{2}, 1950-2012$, were also found in the Yellow River, China (the sixth longest river system in the world, draining $\sim 0.8$ million $\mathrm{km}^{2}$ ). Ran et al. (2015) attributed this to flow regulation by dams that reduced turbidity and extended residence times, thus promoting photosynthesis of aquatic plants and reduced aqueous $\mathrm{CO}_{2}$ concentrations. More recently, Ran et al. (2021) investigated seasonal and annual fluxes of $\mathrm{CO}_{2}$ emissions from streams, 
rivers, lakes, and reservoirs throughout China and quantify their changes over the past 3 decades. They found that the $\mathrm{CO}_{2}$ emissions declined from $138 \pm 31 \mathrm{Tg} \mathrm{Cyr}^{-1}$ in the 1980 s to $98 \pm 19 \mathrm{Tg} \mathrm{C} \mathrm{yr}^{-1}$ in the 2010s. They suggest that this unexpected decrease was driven by a combination of environmental alterations, including massive conversion of free-flowing rivers to reservoirs and widespread implementation of reforestation programs.

\section{The Increase in DOC and OC Burial in Inland Waters in Recent Decades}

As shown above, strengthening of the AP in recent decades has reduced the $\mathrm{pCO}_{2}$ of inland waters due to the photosynthetic consumption of DIC (Liu et al., 2010; Yang et al., 2016; Liu et al., 2018) which, in turn, should increase the DOC concentration (Bianchi et al., 2004; Zhou et al., 2018) and the OC burial (Heathcote and Downing, 2012; Anderson et al., 2013; Brothers et al., 2013; Anderson et al., 2014; Pacheco et al., 2014; Heathcote et al., 2015; Radbourne et al., 2017; Anderson et al., 2020; He et al., 2020).

Reservoir building has resulted in lower velocities and turbidities in many rivers, improving the conditions for photosynthesis and thus contributing more DOC to global fresh waters (Sun et al., 2010). In addition, the increasing nutrient loadings from domestic and agricultural effluents worldwide may also have led to an increased contribution to the DOC flux (Figure 5D). Bianchi et al. (2004) have shown that autochthonous production in rivers may be more important as a source of DOC than previously believed. Increases in nutrient loading (Figures 3E,F) and decreases in suspended loads (because of dams) in the Mississippi River, as well as other large rivers around the world (e.g., Figure 5D), has resulted in significant changes in the sources and overall cycling of riverine DOC.

Heathcote and Downing (2012) evaluated changes in carbon burial rates in several natural lakes in the United States state of Iowa, where the watersheds have been severely altered over the past 150 years. Their remarkable findings (Figure 4C) show the increasing rates of carbon burial in these lakes as agricultural activity intensified. These rates before strong human activities are comparable to worldwide averages for nutrient-poor lakes. However, burial rates have increased to very high levels (up to $200 \mathrm{~g} \mathrm{C} \mathrm{m}^{-2} \mathrm{yr}^{-1}$ ) following agricultural development in most other cases reported.

These studies suggest that anthropogenic change leads to higher OC burial rates by increasing autochthonous and allochthonous carbon fluxes, and that global carbon burial in lakes will become more significant with continuing eutrophication caused by human activities.

Anderson et al. (2013) further suggest that it is land-use change but not climate that causes increases in OC burial in lakes. Pacheco et al. (2014) suggest that, although lakes are important participants in global carbon cycle, the significance of their role may vary with the extent of anthropogenic eutrophication. Geographical regions with abundant surface water supplies can anticipate the development of highly eutrophic lakes because they tend to be more polluted by agriculture and urbanization. They show that enhanced primary production in highly eutrophic lakes can be $\mathrm{CO}_{2}$ sinks by taking up atmospheric $\mathrm{CO}_{2}$ directly. These lakes transform both atmospheric $\mathrm{CO}_{2}$ and DIC into OC, burying some proportion of it in bottom sediments and sending the remainder downstream. Moreover, eutrophication may reverse the role of oligotrophic lakes by enhancing their carbon sequestration ability to store OC (Pacheco et al., 2014). Throughout the course of transition from agriculture to urbanization, levels of eutrophication increase. At the same time, the expected large releases of $\mathrm{CO}_{2}$ into the atmosphere from natural lakes decline substantially (cf. Figures $4 \mathbf{A}, \mathbf{B}$ ), and inland carbon sequestration (cf. Figure 4C) and enrichment of DOC in waters flowing to the sea (Figure 5D) are augmented. Therefore, these authors propose that the global carbon budget should take eutrophication into consideration due to its influence on lakes.

The nitrogen and phosphorus surplus from agriculture development and land use change is causing severe eutrophication in lowland lakes in Europe (Anderson et al., 2014). Although the eutrophication effects on local ecology are understood, their influence on OC burial in lakes and its temporal variation have not been well investigated. These authors also show that the carbon accumulation rate has been high through the 20th Century. Current rates have increased by at least four times compared to background estimates. Their study suggests that lowland European meso-to eutrophic lakes have had OC burial rates more than $50 \mathrm{~g} \mathrm{C} \mathrm{m}^{-2} \mathrm{yr}^{-1}$ over the past century. Heathcote et al. (2015) showed that the burial rates are up to fivefold compared with prior estimates. Although temperatures are higher their rise is not enough to explain the increase in burial. Therefore, other drivers including atmospherically deposited reactive nitrogen are involved.

In Asia, Wang et al. (2018) investigated the temporal-spatial pattern of OC sequestration in Chinese lakes since 1850. They found that the average post-1950 OC burial rates were significantly higher than the 1850-1900 rates. The magnitude of this increase was most marked in the subtropical lakes of the Eastern Plain and on the Yunnan-Guizhou Plateau where the post-1950 OC burial rates was about three times that of 1850-1900, due to the agricultural intensification and urban expansion in recent decades. Moreover, OC burial rates were significantly higher in the Eastern Plain than on the MongoliaXinjiang Plateau (Northeast China) for all time periods. Lake OC burial rates in Yunnan-Guizhou Plateau were significantly higher than rates in the Qinghai-Tibetan Plateau for the post-1950 period and in Mongolia-Xinjiang Plateau for 1850-1900. Regression analyses showed that the controls on lake OC burial rates varied among regions, with catchment climate variables being the most important regulators in MongoliaXinjiang Plateau and Qinghai-Tibetan Plateau, but the in-lake nutrient concentrations were more important in YunnanGuizhou Plateau and Eastern Plain. These results indicate that lakes will become increasingly important for OC burial under future global change scenarios, especially due to intensifying human activities. 
In addition, Brothers et al. (2013) showed that a regime shift from macrophyte to phytoplankton domination boosted carbon burial in a shallow, eutrophic lake with no surface in-or outflows, where sedimentation rates are four times higher than 50 years ago. This change coincided with an ecological regime shift involving the complete loss of submerged macrophytes, leading to a more turbid, phytoplankton-dominated state. To determine if the carbon burial increase is caused by the transformation of carbon cycling pathways coincident with this regime shift, they compared the annual carbon balances of this turbid lake to a neighboring clean lake with similar nutrient concentrations and submerged macrophytes. Results showed that around $80 \%$ of the carbon input was buried permanently in the turbid lake sediments, but only $40 \%$ in the clean lake. The reason is that a turbid lake buries carbon more rapidly due to lower benthic carbon mineralization rates (Brothers et al., 2013). The latter were linked to a decline in benthic oxygen availability coinciding with the loss of submerged macrophytes. In contrast to previous assumptions that a regime shift to phytoplankton dominance decreases lake heterotrophy by boosting whole-lake primary production, their results suggest that an equivalent net metabolic shift may also result from lower carbon mineralization rates in shallow, turbid lakes. The widespread occurrence of such shifts thus may fundamentally alter the role of shallow lakes in the global carbon cycle, away from channeling terrestrial carbon to the atmosphere and towards burying increasing amounts of it (Brothers et al., 2013).

More recently, Anderson et al. (2020) have reported global and biome specific trajectories of lake $\mathrm{C}$ sequestration based on 516 lakes and showed that some lake $\mathrm{C}$ burial rates (i.e., those in tropical forest and grassland biomes) have quadrupled over the last 100 years. They found that global lake C-sequestration $\left(\sim 120 \mathrm{Tg}_{\text {year }}{ }^{-1}\right)$ has increased by $\sim 72 \mathrm{Tg}$ year $^{-1}$ since 1900 , offsetting $20 \%$ of annual $\mathrm{CO}_{2}$ freshwater emissions rising to $\sim 30 \%$ if reservoirs are included and contributing to the residual continental $\mathrm{C}$ sink. They further indicated that nutrient availability explains $\sim 70 \%$ of the observed increase, while rising temperatures have a minimal effect. In addition, though increased gross primary production (GPP) in rivers and streams is often accompanied by increased ecosystem respiration (ER) (Hosen et al., 2019), GPP increased more than ER especially during drought, even leading to temporary autotrophy, an otherwise rare event in the typically light-limited heterotrophic river main stem. With climate change, rivers and streams may become warmer and drought frequency and severity may increase. Such changes may increase autotrophy in rivers with broad implications for carbon cycling in aquatic ecosystems (Hosen et al., 2019).

\section{IMPLICATIONS FOR ESTIMATIONS OF THE MISSING CARBON SINK}

As shown above, the AP in inland waters has strengthened significantly in the recent past, indicated by decreasing $\mathrm{CO}_{2}$ emissions and increasing DOC flux and OC burial (storage) in world rivers, lakes and reservoirs (Figures 3-5). Both the decreasing $\mathrm{CO}_{2}$ emissions and the increasing $\mathrm{OC}$ burial can be considered as missing carbon sinks, which will be estimated below.

\section{Estimation of the Missing Carbon Sink Based on Decreasing $\mathrm{CO}_{2}$ Emissions}

Wang et al. (2007) have demonstrated that the average $\mathrm{CO}_{2}$ degassing flux to the atmosphere from the Yangtze River declined by $\sim 75 \%$ over the period from the 1960 s to the 1990 s. Jones et al. (2003) found that $\mathrm{pCO}_{2}$ in 417 streams and rivers throughout the contiguous United States declined 58\% from 1973 to 1994. For the Mississippi River, the decrease in dissolved $\mathrm{CO}_{2}$ was also large, amounting up to $50 \%$ during the past 55 years from 1963 to 2018 [Figure 3, U.S. Geological Survey (USGS) site 07373420, near St. Francisville, LA; $30^{\circ} 45^{\prime} 30^{\prime \prime}, 91^{\circ} 23^{\prime} 45^{\prime \prime}$, https://waterdata. usgs.gov/nwis].

If we take $50 \%$ as the conservative estimate for the decrease in the $\mathrm{CO}_{2}$ degassing flux in inland waters in these recent decades, with $2.1 \mathrm{GtC} \mathrm{yr}^{-1}$ (Raymond et al., 2013) and $0.75 \mathrm{GtC} \mathrm{yr}^{-1}$ (Cole et al., 2007) as the maximum and minimum global $\mathrm{CO}_{2}$ emissions from inland waters respectively, then a maximum value of $1.0 \mathrm{Gt} \mathrm{C} \mathrm{yr}^{-1}$ and a minimum of $0.38 \mathrm{Gt} \mathrm{C} \mathrm{yr}^{-1}$ are obtained for the missing carbon sink. The role of the AP here needs to be determined quantitatively in the future by distinguishing between the decline in terrestrial $\mathrm{CO}_{2}$ production plus import into aquatic ecosystems (Jones et al., 2003; Maberly et al., 2013; Campeau et al., 2019) and the decrease in $\mathrm{CO}_{2}$ caused by increased AP (Wang et al., 2007; Ran et al., 2015; Ran et al., 2021).

\section{Estimation of the Missing Carbon Sink Based on Increasing OC Burial}

Anderson et al. (2013), Anderson et al. (2014), and Anderson et al. (2020) have shown that, compared to background estimates of OC burial, contemporary rates have increased at least three to fivefold.

If we take three-fold (Anderson et al., 2013) as the conservative estimate for the increase in OC burial flux in inland waters in the

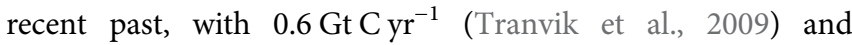
$0.2 \mathrm{Gt} \mathrm{C} \mathrm{yr}^{-1}$ (Cole et al., 2007) as maximum and minimum global OC burial rates in inland waters respectively, then a maximum of $1.8 \mathrm{Gt} \mathrm{C} \mathrm{yr}^{-1}$ and a minimum of $0.6 \mathrm{Gt} \mathrm{C} \mathrm{yr}^{-1}$ are obtained for the missing carbon sink, which are the same order of magnitude as those obtained above for the estimates of decreasing $\mathrm{CO}_{2}$ emissions. This may indicate that it is highly likely that the increasing $\mathrm{OC}$ burial and decreasing $\mathrm{CO}_{2}$ emissions are together due to the strengthening of the AP in inland waters, an important contributor to the missing carbon sink.

Finally, the persistence of autochthonous production derived organic carbon deserves short discussion here. It is commonly assumed that autochthonous organic carbon is easier to be decomposed. However, this depends on the environmental conditions (Gudasz et al., 2015; Katsev and Crowe, 2015; Guillemette et al., 2017; Huang et al., 2017; Radbourne et al., 2017). For example, Radbourne et al. (2017) found that most of 
the autochthonous OC is preserved (similar to $95 \%$ of OC captured in the deep trap and $86 \%$ of the NEP in the contemporary system), which is contrary to the widely held assumption that this more labile, algal-dominated OC component is not well preserved in lake sediments. According to our study in Fuxian Lake, there was little change in the proportion of autochthonous OC, which accounted for more than $50 \%$ of OC during the past century (He et al., 2020). Similar results are obtained by Heatcote and Downing (2012) in a suite of natural lakes in the United States state of Iowa, and Huang et al. (2017) in western and northern Dianchi Lake, SW China.

\section{CONCLUSION AND FUTURE RESEARCH DIRECTIONS}

We have shown that the AP in inland waters appears to have been strengthening in response to global changes of climate and land use, as evidenced by decreasing $\mathrm{CO}_{2}$ emissions from, and increasing DOC storage and $\mathrm{OC}$ burial in, inland waters during recent decades. We estimate that the missing carbon sink associated with this strengthening may range from 0.38 to $1.8 \mathrm{Gt} \mathrm{C} \mathrm{yr}^{-1}$. Our study stresses the potential role that the AP may play in the further evolution of the global carbon cycle. However, to determine quantitatively the role played by this mechanism, the following needs to be done in future work:

1) Treat changes in DIC (including $\mathrm{pCO}_{2}$ ), DOC and buried OC simultaneously in a given inland water ecosystem to fully describe the AP effect

Although some global-scale studies have examined specific processes such as carbon burial and $\mathrm{CO}_{2}$ exchange with the atmosphere, most studies of lake carbon cycling are from single systems, focus only on a specific habitat, and do not account for all of the major terms in OC budgets. Hence, most lake OC budgets are incomplete, leaving some key processes highly uncertain. To advance the analysis of the role of the inland waters in carbon cycling, ecosystem science needs a new generation of studies that confront these shortcomings (Cole et al., 2007; Battin et al., 2009; Tranvik et al., 2009; Hanson et al., 2015).

The future final quantification of the freshwater AP effect on the carbon cycle, therefore, should contribute to policies to reduce carbon emissions and increase carbon sinks in terrestrial aquatic ecosystems.

2) Monitor the long-term changes in these parameters to understand the AP responses to changes in climate and land use

Understanding the variability of DIC (including $\mathrm{CO}_{2}$ ), DOC and OC burial through long-term studies is crucial to capture the patterns and drivers influencing sources of these components at scales relevant to decision-making (Jones et al., 2003; Raymond and Cole, 2003; Wang et al., 2007; Downing et al., 2008; Raymond et al., 2008; Finlay et al., 2009; Sun et al., 2010; Heathcote and
Downing, 2012; Finlay et al., 2015; Ran et al., 2015; Drake et al., 2018).

3) Partition between autochthonous and allochthonous OC in inland waters

Key problems in understanding OC budgets are the partitioning between autochthonous and allochthonous sources (Waterson and Canuel, 2008; Yang et al., 2016; Huang et al., 2017; Radbourne et al., 2017; Huang et al., 2018; He et al., 2020), resolving the spatial heterogeneity and temporal dynamics in inputs and their transformations, and measuring critical processes such as burial of OC at temporal scales suitable for resolving annual budgets (Hanson et al., 2015).

4) Understand the limitation of nutrients, especially $\mathrm{CO}_{2}$, on the primary production or eutrophication in different inland waters

The unique property of $\mathrm{CO}_{2}$ in the biosphere is its conversion to biomass through photosynthesis. The research interest in $\mathrm{CO}_{2}$ as a key nutrient (King, 1970; Schindler and Fee 1973; Riebesell et al., 1993; Kaplan and Reinhold, 1999; Jansson et al., 2012; LowDecarie et al., 2014; Kragh and Sand-Jensen, 2018; Zeng et al., 2019) is related to its ready global availability compared to other resources, especially phosphorus and nitrogen (Schindler, 1977; Smith et al., 1999). The limited role assigned to $\mathrm{CO}_{2}$ in restricting productivity is based on the assumption that only a single nutrient can control it at any given time. However, LowDecarie et al. (2015) suggest that $\mathrm{CO}_{2}$ can function as a ratelimiting rather than a yield-limiting resource (phosphorus is a yield-limiting resource), and that it can interact with other resources in the co-limitation of productivity. $\mathrm{CO}_{2}$ can limit the productivity of eutrophic lakes in cases where photosynthesis exceeds diffusive influx from the atmosphere (Kaplan and Reinhold, 1999). Jansson et al. (2012) found that even in lakes where phosphorus limitation is present, $\mathrm{CO}_{2}$ supersaturation strengthens primary productivity ten times more than in the same system in equilibrium with the atmosphere.

In addition, $\mathrm{CO}_{2}$ accessibility can be limited even when carbon is abundantly available in other forms (e.g., $\mathrm{HCO}_{3}{ }^{-}$), as is the case in aqueous systems with high pH (Riebesell et al., 1993; Kragh and Sand-Jensen, 2018).

Furthermore, most marine and freshwater phytoplankton have inducible carbon concentration mechanisms that assist in raising $\mathrm{CO}_{2}$ concentration at the site of photosynthesis (Kragh and Sand-Jensen, 2018).

5) Pay attention to the importance of aquatic community structure and composition in the AP process

The efficiency of the AP is a function of the physiology and community structure of the phytoplankton and submerged plants, which in turn are governed by the physical and chemical conditions of inland waters (Findlay and Kasian, 1987; Low-Decarie et al., 2011; Brothers et al., 2013; LowDecarie et al., 2014; Low-Decarie et al., 2015; Basu and 
Mackey, 2018). However, few studies have focused on the importance of aquatic community structure and composition to AP.

Since global change is projected to affect carbon and nutrient availability, temperature and light, a better understanding of how aquatic community structures will respond in the future is needed to gain knowledge about the AP and the capacity of the inland waters to function as both long-term and short-term sinks for atmospheric $\mathrm{CO}_{2}$ (Low-Decarie et al., 2014; Shen et al., 2018).

6) Extend the geographical distribution of research areas to improve the AP data base

As is seen in Figure 2, though the decrease in $\mathrm{CO}_{2}$ degassing flux and increase in DOC concentration and carbon burial seem to be global phenomena both in rivers and lakes/reservoirs influenced by anthropogenic activity and climate change, longterm monitoring and investigations need to be extended to wider geographical areas, not merely in Europe, Asia and North America as at present, but also to South America, Africa and Oceania to increase the world representativeness.

\section{REFERENCES}

Anderson, N. J., Bennion, H., and Lotter, A. F. (2014). Lake Eutrophication and its Implications for Organic Carbon Sequestration in Europe. Glob. Change Biol. 20, 2741-2751. doi:10.1111/gcb.12584

Anderson, N. J., Dietz, R. D., and Engstrom, D. R. (2013). Land-use Change, Not Climate, Controls Organic Carbon Burial in Lakes. Proc. R. Soc. B. 280, 20131278. doi:10.1098/rspb.2013.1278

Anderson, N. J., Heathcote, A. J., Engstrom, D. R., Ryves, D. B., Mills, K., et al. (2020). Anthropogenic Alteration of Nutrient Supply Increases the Global Freshwater Carbon Sink. Sci. Adv. 6, eaaw2145. doi:10.1126/sciadv.aaw2145

Ballantyne, A. P., Alden, C. B., Miller, J. B., Tans, P. P., and White, J. W. C. (2012). Increase in Observed Net Carbon Dioxide Uptake by Land and Oceans during the Past 50 Years. Nature 488, 70-72. doi:10.1038/nature11299

Basu, S., and Mackey, K. (2018). Phytoplankton as Key Mediators of the Biological Carbon Pump: Their Responses to a Changing Climate. Sustainability 10, 869. doi:10.3390/su10030869

Battin, T. J., Luyssaert, S., Kaplan, L. A., Aufdenkampe, A. K., Richter, A., and Tranvik, L. J. (2009). The Boundless Carbon Cycle. Nat. Geosci 2, 598-600. doi:10.1038/ngeo618

Bianchi, T. S., Filley, T., Dria, K., and Hatcher, P. G. (2004). Temporal Variability in Sources of Dissolved Organic Carbon in the Lower Mississippi River. Geochimica et Cosmochimica Acta 68, 959-967. doi:10.1016/j.gca.2003.07.011

Broecker, W. S., and Peng, T. S. (1998). Greenhouse Puzzles. 2nd ed. Palisades: Eldigio Press.

Broecker, W. S., Takahashi, T., Simpson, H. J., and Peng, T.-H. (1979). Fate of Fossil Fuel Carbon Dioxide and the Global Carbon Budget. Science 206, 409-418. doi:10.1126/science.206.4417.409

Brothers, S. M., Hilt, S., Attermeyer, K., Grossart, H. P., Kosten, S., Lischke, B., et al. (2013). A Regime Shift from Macrophyte to Phytoplankton Dominance Enhances Carbon Burial in a Shallow, Eutrophic lake. Ecosphere 4, UNSP 137. doi:10.1890/es13-00247.1

Campeau, A., Bishop, K., Amvrosiadi, N., Billett, M. F., Garnett, M. H., Laudon, H., et al. (2019). Current forest Carbon Fixation Fuels Stream CO2 Emissions. Nat. Commun. 10, 1876. doi:10.1038/s41467-019-09922-3

Cardille, J. A., Carpenter, S. R., Coe, M. T., Foley, J. A., Hanson, P. C., Turner, M. G., et al. (2007). Carbon and Water Cycling in lake-rich Landscapes: Landscape Connections, lake Hydrology, and Biogeochemistry. J. Geophys. Res. 112, G02031. doi:10.1029/2006jg000200

\section{AUTHOR CONTRIBUTIONS}

ZL developed the research concept and wrote the manuscript. SZ and $\mathrm{HY}$ collected the data and generated the figures. All authors contributed to the revisions and approved the final version of this manuscript.

\section{FUNDING}

This work was supported by the National Natural Science Foundation of China (41921004, U1612441) and the Strategic Priority Research Program of Chinese Academy of Sciences (Grant No. XDB 40020000).

\section{ACKNOWLEDGMENTS}

Special thanks are given to Prof. Dr. Derek Ford (McMaster University, Canada) for his thoughtful comments and corrections, which greatly improved the original draft.

Ciais, P., Sabine, C., Bala, G., Bopp, L., Brovkin, V., and Canadell, J. (2013). in Climate Change 2013: The Physical Science Basis. Contribution of Working Group I to the Fifth Assessment Report of the Intergovernmental Panel on Climate Change. Editors (Cambridge, United Kingdom: Cambridge University Press), p465-570.

Cole, J. J., Prairie, Y. T., Caraco, N. F., McDowell, W. H., Tranvik, L. J., Striegl, R. G., et al. (2007). Plumbing the Global Carbon Cycle: Integrating Inland Waters into the Terrestrial Carbon Budget. Ecosystems 10, 171-184. doi:10.1007/s10021006-9013-8

Dean, W. E., and Gorham, E. (1998). Magnitude and Significance of Carbon Burial in Lakes, Reservoirs, and Peatlands. Geol. 26, 535-538. doi:10.1130/00917613(1998)026<0535:masocb > 2.3.co;2

Downing, J. A., Cole, J. J., Middelburg, J. J., Striegl, R. G., Duarte, C. M., Kortelainen, P., et al. (2008). Sediment Organic Carbon Burial in Agriculturally Eutrophic Impoundments over the Last century. Glob. Biogeochem. Cy. 22, GB1018. doi:10.1029/2006gb002854

Drake, T. W., Tank, S. E., Zhulidov, A. V., Holmes, R. M., Gurtovaya, T., and Spencer, R. G. M. (2018). Increasing Alkalinity Export from Large Russian Arctic Rivers. Environ. Sci. Technol. 52, 8302-8308. doi:10.1021/acs.est.8b01051

Einsele, G., Yan, J., and Hinderer, M. (2001). Atmospheric Carbon Burial in Modern lake Basins and its Significance for the Global Carbon Budget. Glob. Planet. Change 30, 167-195. doi:10.1016/s0921-8181(01)00105-9

Findlay, D. L., and Kasian, S. E. M. (1987). Phytoplankton Community Responses to Nutrient Addition in Lake 226, Experimental Lakes Area, Northwestern Ontario. Can. J. Fish. Aquat. Sci. 44, s35-s46. doi:10.1139/f87-278

Finlay, K., Leavitt, P. R., Wissel, B., and Prairie, Y. T. (2009). Regulation of Spatial and Temporal Variability of Carbon Flux in Six Hard-Water Lakes of the Northern Great Plains. Limnol. Oceanogr. 54, 2553-2564. doi:10.4319/ lo.2009.54.6_part_2.2553

Finlay, K., Vogt, R. J., Bogard, M. J., Wissel, B., Tutolo, B. M., Simpson, G. L., et al. (2015). Decrease in CO2 Efflux from Northern Hardwater Lakes with Increasing Atmospheric Warming. Nature 519, 215-218. doi:10.1038/ nature 14172

Flanagan, K. M., Mccauley, E., and Wrona, F. (2006). Freshwater Food Webs Control Carbon Dioxide Saturation through Sedimentation. Glob. Change Biol. 12, 644-651. doi:10.1111/j.1365-2486.2006.01127.x

Gudasz, C., Sobek, S., Bastviken, D., Koehler, B., and Tranvik, L. J. (2015). Temperature Sensitivity of Organic Carbon Mineralization in Contrasting lake Sediments. J. Geophys. Res. Biogeosci. 120, 1215-1225. doi:10.1002/ 2015jg002928 
Guillemette, F., von Wachenfeldt, E., Kothawala, D. N., Bastviken, D., and Tranvik, L. J. (2017). Preferential Sequestration of Terrestrial Organic Matter in Boreal lake Sediments. J. Geophys. Res. Biogeosci. 122, 863-874. doi:10.1002/ 2016jg003735

Hanson, P. C., Pace, M. L., Carpenter, S. R., Cole, J. J., and Stanley, E. H. (2015). Integrating Landscape Carbon Cycling: Research Needs for Resolving Organic Carbon Budgets of Lakes. Ecosystems 18, 363-375. doi:10.1007/s10021-0149826-9

Hanson, P. C., Pollard, A. I., Bade, D. L., Predick, K., Carpenter, S. R., and Foley, J. A. (2004). A Model of Carbon Evasion and Sedimentation in Temperate Lakes. Glob. Change Biol. 10, 1285-1298. doi:10.1111/j.1529-8817.2003.00805.x

He, H., Liu, Z., Chen, C., Wei, Y., Bao, Q., Sun, H., et al. (2020). The Sensitivity of the Carbon Sink by Coupled Carbonate Weathering to Climate and Land-Use Changes: Sediment Records of the Biological Carbon Pump Effect in Fuxian Lake, Yunnan, China, during the Past century. Sci. Total Environ. 720, 137539. doi:10.1016/j.scitotenv.2020.137539

Heathcote, A. J., Anderson, N. J., Prairie, Y. T., Engstrom, D. R., and del Giorgio, P. A. (2015). Large Increases in Carbon Burial in Northern Lakes during the Anthropocene. Nat. Commun. 6, 10016. doi:10.1038/ncomms10016

Heathcote, A. J., and Downing, J. A. (2012). Impacts of Eutrophication on Carbon Burial in Freshwater Lakes in an Intensively Agricultural Landscape. Ecosystems 15, 60-70. doi:10.1007/s10021-011-9488-9

Hosen, J. D., Aho, K. S., Appling, A. P., Creech, E. C., Fair, J. H., Hall, R. O., et al. (2019). Enhancement of Primary Production during Drought in a Temperate Watershed Is Greater in Larger Rivers Than Headwater Streams. Limnol. Oceanogr. 64, 1458-1472. doi:10.1002/lno.11127

Houghton, J. T., Jenkins, G. J., and Ephraums, J. J. (1990). Climate Change: The IPCC Assessment. London: Cambridge University Press.

Houghton, R. A., Baccini, A., and Walker, W. S. (2018). Where Is the Residual Terrestrial Carbon Sink? Glob. Change Biol. 24, 3277-3279. doi:10.1111/ gcb. 14313

Houghton, R. A. (2007). Balancing the Global Carbon Budget. Annu. Rev. Earth Planet. Sci. 35, 313-347. doi:10.1146/annurev.earth.35.031306.140057

Houghton, R. A. (2003). Why Are Estimates of the Terrestrial Carbon Balance So Different? Glob. Change Biol. 9, 500-509. doi:10.1046/j.1365-2486.2003.00620.x

Huang, C., Yao, L., Zhang, Y., Huang, T., Zhang, M., Zhu, A.-X., et al. (2017). Spatial and Temporal Variation in Autochthonous and Allochthonous Contributors to Increased Organic Carbon and Nitrogen Burial in a Plateau lake. Sci. Total Environ. 603-604, 390-400. doi:10.1016/j.scitotenv.2017.06.118

Huang, C., Zhang, L., Li, Y., Lin, C., Huang, T., Zhang, M., et al. (2018). Carbon and Nitrogen Burial in a Plateau lake during Eutrophication and Phytoplankton Blooms. Sci. Total Environ. 616-617, 296-304. doi:10.1016/ j.scitotenv.2017.10.320

Jansson, M., Karlsson, J., and Jonsson, A. (2012). Carbon Dioxide Supersaturation Promotes Primary Production in Lakes. Ecol. Lett. 15, 527-532. doi:10.1111/ j.1461-0248.2012.01762.x

Jones, J. B., Stanley, E. H., and Mulholland, P. J. (2003). Long-term Decline in Carbon Dioxide Supersaturation in Rivers across the Contiguous United States. Geophys. Res. Lett. 30, 1495. doi:10.1029/2003gl017056

Kaplan, A., and Reinhold, L. (1999). Co2Concentrating Mechanisms in Photosynthetic Microorganisms. Annu. Rev. Plant Physiol. Plant Mol. Biol. 50, 539-570. doi:10.1146/annurev.arplant.50.1.539

Katsev, S., and Crowe, S. A. (2015). Organic Carbon Burial Efficiencies in Sediments: The Power Law of Mineralization Revisited. Geology 43, 607-610. doi:10.1130/g36626.1

Kheshgi, H. S., Jain, A. K., and Wuebbles, D. J. (1996). Accounting for the Missing Carbon-Sink with the CO2-fertilization Effect. Climatic Change 33, 31-62. doi:10.1007/bf00140512

King, A. W., Emanuel, W. R., Wullschleger, S. D., and Post, W. M. (1995). In Search of the Missing Carbon Sink: a Model of Terrestrial Biospheric Response to Land-Use Change and Atmospheric CO2. Tellus B 47, 501-519. doi:10.1034/ j.1600-0889.47.issue4.9.x

King, D. L. (1970). The Role of Carbon in Eutrophication. J. Water Pollut. Contr. Fed. 42, 20352051.

Kirschbaum, M. U. F., Zeng, G., Ximenes, F., Giltrap, D. L., and Zeldis, J. R. (2019). Towards a More Complete Quantification of the Global Carbon Cycle. Biogeosciences 16, 831-846. doi:10.5194/bg-16-831-2019
Knoll, L. B., Vanni, M. J., Renwick, W. H., Dittman, E. K., and Gephart, J. A. (2013). Temperate Reservoirs Are Large Carbon Sinks and Small CO2sources: Results from High-Resolution Carbon Budgets. Glob. Biogeochem. Cycles 27, 52-64. doi:10.1002/gbc.20020

Kragh, T., and Sand-Jensen, K. (2018). Carbon Limitation of lake Productivity. Proc. R. Soc. B. 285, 20181415. doi:10.1098/rspb.2018.1415

Liu, Z., Dreybrodt, W., and Wang, H. (2010). A New Direction in Effective Accounting for the Atmospheric $\mathrm{CO} 2$ Budget: Considering the Combined Action of Carbonate Dissolution, the Global Water Cycle and Photosynthetic Uptake of DIC by Aquatic Organisms. Earth-Science Rev. 99, 162-172. doi:10.1016/j.earscirev.2010.03.001

Liu, Z., Macpherson, G. L., Groves, C., Martin, J. B., Yuan, D., and Zeng, S. (2018). Large and Active $\mathrm{CO} 2$ Uptake by Coupled Carbonate Weathering. EarthScience Rev. 182, 42-49. doi:10.1016/j.earscirev.2018.05.007

Low-Décarie, E., Bell, G., and Fussmann, G. F. (2015). CO2 Alters Community Composition and Response to Nutrient Enrichment of Freshwater Phytoplankton. Oecologia 177, 875-883. doi:10.1007/s00442-014-3153-x

Low-Décarie, E., Fussmann, G. F., and Bell, G. (2014). Aquatic Primary Production in a high-CO2 World. Trends Ecol. Evol. 29, 223-232. doi:10.1016/ j.tree.2014.02.006

Low-décarie, E., Fussmann, G. F., and Bell, G. (2011). The Effect of Elevated CO2 on Growth and Competition in Experimental Phytoplankton Communities. Glob. Change Biol. 17, 2525-2535. doi:10.1111/j.1365-2486.2011.02402.x

Maberly, S. C., Barker, P. A., Stott, A. W., and De Ville, M. M. (2013). Catchment Productivity Controls $\mathrm{CO} 2$ Emissions from Lakes. Nat. Clim Change 3, 391-394. doi:10.1038/nclimate 1748

Melnikov, N. B., and O'Neill, B. C. (2006). Learning about the Carbon Cycle from Global Budget Data. Geophys. Res. Lett. 33, L027052006. doi:10.1029/ 2005gl023935

Mulholland, P. J., and Elwood, J. W. (1982). The Role of lake and Reservoir Sediments as Sinks in the Perturbed Global Carbon Cycle. Tellus 34, 490-499. doi:10.3402/tellusa.v34i5.10834

Nadelhoffer, K. J., Emmett, B. A., Gundersen, P., Kjønaas, O. J., Koopmans, C. J., Schleppi, P., et al. (1999). Nitrogen Deposition Makes a Minor Contribution to Carbon Sequestration in Temperate Forests. Nature 398, 145-148. doi:10.1038/ 18205

Nydahl, A. C., Wallin, M. B., and Weyhenmeyer, G. A. (2017). No Long-Term Trends in P CO2 Despite Increasing Organic Carbon Concentrations in Boreal Lakes, Streams, and Rivers. Glob. Biogeochem. Cycles 31, 985-995. doi:10.1002/ 2016gb005539

Pacheco, F., Roland, F., and Downing, J. (2014). Eutrophication Reverses Wholelake Carbon Budgets. Iw 4, 41-48. doi:10.5268/iw-4.1.614

Radbourne, A. D., Ryves, D. B., Anderson, N. J., and Scott, D. R. (2017). The Historical Dependency of Organic Carbon Burial Efficiency. Limnol. Oceanogr. 62, 1480-1497. doi:10.1002/Ino.10512

Ran, L., Butman, D. E., Battin, T. J., Yang, X., Tian, M., Duvert, C., et al. (2021). Substantial Decrease in $\mathrm{CO} 2$ Emissions from Chinese Inland Waters Due to Global Change. Nat. Commun. 12, 1730. doi:10.1038/s41467-021-21926-6

Ran, L., Lu, X. X., Richey, J. E., Sun, H., Han, J., Yu, R., et al. (2015). Long-term Spatial and Temporal Variation of CO2 Partial Pressure in the Yellow River, China. Biogeosciences 12, 921-932. doi:10.5194/bg-12-921-2015

Raymond, P. A., and Cole, J. J. (2003). Increase in the export of Alkalinity from North America's Largest River. Science 301, 88-91. doi:10.1126/ science. 1083788

Raymond, P. A., Hartmann, J., Lauerwald, R., Sobek, S., McDonald, C., Hoover, M., et al. (2013). Global Carbon Dioxide Emissions from Inland Waters. Nature 503, 355-359. doi:10.1038/nature 12760

Raymond, P. A., Oh, N.-H., Turner, R. E., and Broussard, W. (2008). Anthropogenically Enhanced Fluxes of Water and Carbon from the Mississippi River. Nature 451, 449-452. doi:10.1038/nature06505

Richey, J. E., Melack, J. M., Aufdenkampe, A. K., Ballester, V. M., and Hess, L. L. (2002). Outgassing from Amazonian Rivers and Wetlands as a Large Tropical Source of Atmospheric CO2. Nature 416, 617-620. doi:10.1038/ $416617 \mathrm{a}$

Riebesell, U., Wolf-Gladrow, D. A., and Smetacek, V. (1993). Carbon Dioxide Limitation of marine Phytoplankton Growth Rates. Nature 361, 249-251. doi:10.1038/361249a 0 
Sabine, C. L., Heimann, M., Artaxo, P., Bakker, D. C. E., Chen, C. A., Field, C. B., et al. (2004). "Current Status and Past Trends of the Carbon Cycle," in The Global Carbon Cycle: Integrating Humans, Climate, and the Natural World. Editors C. B. Field and M. R. Raupach (Washington DC: Island Press), p17-44.

Schindler, D. W., and Bayley, S. E. (1993). The Biosphere as an Increasing Sink for Atmospheric Carbon: Estimates from Increased Nitrogen Depostion. Glob. Biogeochem. Cycles 7, 717-733. doi:10.1029/93gb02562

Schindler, D. W. (1977). Evolution of Phosphorus Limitation in Lakes. Science 195, 260-262. doi:10.1126/science.195.4275.260

Schindler, D. W., and Fee, E. J. (1973). Diurnal Variation of Dissolved Inorganic Carbon and its Use in Estimating Primary Production and CO2 Invasion in Lake 227. J. Fish. Res. Bd. Can. 30, 1501-1510. doi:10.1139/f73-240

Schindler, D. W. (1999). The Mysterious Missing Sink. Nature 398, 105-107. doi:10.1038/18111

Shen, J., Pearson, A., Henkes, G. A., Zhang, Y. G., Chen, K., Li, D., et al. (2018). Improved Efficiency of the Biological Pump as a Trigger for the Late Ordovician Glaciation. Nat. Geosci. 11, 510-514. doi:10.1038/s41561-018-0141-5

Smith, V. H., Tilman, G. D., and Nekola, J. C. (1999). Eutrophication: Impacts of Excess Nutrient Inputs on Freshwater, marine, and Terrestrial Ecosystems. Environ. Pollut. 100, 179-196. doi:10.1016/s0269-7491(99)00091-3

Stallard, R. F. (1998). Terrestrial Sedimentation and the Carbon Cycle: Coupling Weathering and Erosion to Carbon Burial. Glob. Biogeochem. Cycles 12, 231-257. doi:10.1029/98gb00741

Sun, H. G., Han, J., Lu, X. X., Zhang, S. R., and Li, D. (2010). An Assessment of the Riverine Carbon Flux of the Xijiang River during the Past 50 Years. Quat. Int. 226, 38-43. doi:10.1016/j.quaint.2010.03.002

Tans, P. P., Fung, I. Y., and Takahashi, T. (1990). Observational Contrains on the Global Atmospheric Co2 Budget. Science 247, 1431-1438. doi:10.1126/ science.247.4949.1431

Tranvik, L. J., Downing, J. A., Cotner, J. B., Loiselle, S. A., Striegl, R. G., Ballatore, T. J., et al. (2009). Lakes and Reservoirs as Regulators of Carbon Cycling and Climate. Limnol. Oceanogr. 54, 2298-2314. doi:10.4319/lo.2009.54.6_part_2.2298

Vitousek, P. M., Aber, J. D., Howarth, R. W., Likens, G. E., Matson, P. A., Schindler, D. W., et al. (1997). Human Alteration of the Global Nitrogen Cycle: Sources and Consequences. Ecol. Appl. 7, 737-750. doi:10.1890/1051-0761(1997)007 [0737:haotgn]2.0.co;2

Wang, F., Wang, Y., Zhang, J., Xu, H., and Wei, X. (2007). Human Impact on the Historical Change of CO2degassing Flux in River Changjiang. Geochem. Trans. 8, 7. doi:10.1186/1467-4866-8-7
Wang, M., Wu, J., Chen, H., Yu, Z., Zhu, Q. a., Peng, C., et al. (2018). Temporalspatial Pattern of Organic Carbon Sequestration by Chinese Lakes since 1850 Limnol. Oceanogr. 63, 1283-1297. doi:10.1002/lno.10771

Waterson, E. J., and Canuel, E. A. (2008). Sources of Sedimentary Organic Matter in the Mississippi River and Adjacent Gulf of Mexico as Revealed by Lipid Biomarker and 813 CTOC Analyses. Org. Geochem. 39, 422-439. doi:10.1016/ j.orggeochem.2008.01.011

Yang, M., Liu, Z., Sun, H., Yang, R., and Chen, B. (2016). Organic Carbon Source Tracing and DIC Fertilization Effect in the Pearl River: Insights from Lipid Biomarker and Geochemical Analysis. Appl. Geochem. 73, 132-141. doi:10.1016/j.apgeochem.2016.08.008

Zeng, S., Liu, H., Liu, Z., Kaufmann, G., Zeng, Q., and Chen, B. (2019). Seasonal and Diurnal Variations in DIC, NO3- and TOC Concentrations in springpond Ecosystems under Different Land-Uses at the Shawan Karst Test Site, SW China: Carbon Limitation of Aquatic Photosynthesis. J. Hydrol. 574, 811-821. doi:10.1016/j.jhydrol.2019.04.090

Zhou, Y., Davidson, T. A., Yao, X., Zhang, Y., Jeppesen, E., de Souza., J. G., et al. (2018). How Autochthonous Dissolved Organic Matter Responds to Eutrophication and Climate Warming: Evidence from a Cross-continental Data Analysis and Experiments. Earth-Science Rev. 185, 928-937. doi:10.1016/j.earscirev.2018.08.013

Conflict of Interest: The authors declare that the research was conducted in the absence of any commercial or financial relationships that could be construed as a potential conflict of interest.

Publisher's Note: All claims expressed in this article are solely those of the authors and do not necessarily represent those of their affiliated organizations, or those of the publisher, the editors and the reviewers. Any product that may be evaluated in this article, or claim that may be made by its manufacturer, is not guaranteed or endorsed by the publisher.

Copyright (c) 2021 Liu, Yan and Zeng. This is an open-access article distributed under the terms of the Creative Commons Attribution License (CC BY). The use, distribution or reproduction in other forums is permitted, provided the original author(s) and the copyright owner(s) are credited and that the original publication in this journal is cited, in accordance with accepted academic practice. No use, distribution or reproduction is permitted which does not comply with these terms. 